\title{
MONETARY POLICY REACTION FunCTION IN POSITIVE AND NORMATIVE APPROACHES: EVIDENCE FROM ASEAN-3
}

\section{Pei-Tha Gan*}

Department of Economics, Faculty of Management and Economics Universiti Pendidikan Sultan Idris (Sultan Idris Education University) 35900 Tanjong Malim, Perak,

Malaysia

\section{Kok-Jing Yee}

Department of Economics, Faculty of Management and Economics Universiti Pendidikan Sultan Idris (Sultan Idris Education University) 35900 Tanjong Malim, Perak, Malaysia

\section{Norimah Rambeli@Ramli}

Department of Economics, Faculty of Management and Economics Universiti Pendidikan Sultan Idris (Sultan Idris Education University) 35900 Tanjong Malim, Perak,

Malaysia

\section{Norasibah Abdul Jalil}

Department of Economics, Faculty of Management and Economics Universiti Pendidikan Sultan Idris (Sultan Idris Education University) 35900 Tanjong Malim, Perak, Malaysia

*Corrosponding author’s Email: gan.pt@fpe.upsi.edu.my 


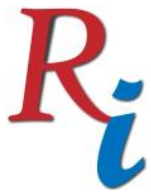

\section{Asia Proceedings of Social Sciences}

(APSS)

www.readersinsight.net/APSS

\section{A b s t r a c t}

A notable feature in many mainstream economic theories and empirical works of literature has been emphasized the conventional development in the domestic economic factors in dealing with monetary policy in both positive and normative approaches. However, external economic factors consist of potentially valuable information, such as the exchange rate and terms of trade, that cannot simply be ignored. To address this limitation, this study examines the monetary policy reaction function in an open economic model in both positive and normative approaches that encompasses the domestic and external factors, namely the inflation, the output gap, the exchange rate and the terms of trade. The empirical validity is obtained by using a sample of ASEAN-3 countries. Both the positive and normative approaches adopt the generalized method of moments and the grid search method, respectively. The findings deliver some policy implications; monetary policy via interest rate remains an important strategy in absorbing shocks from domestic and external factors, and the central bank should include important factors, namely the inflation, the output gap, the exchange rate and the terms of trade, in its monetary policy decision making that eventually help to attain the best economic outcomes.

\section{Research High I ight s}

First, Monetary policy via interest rate remains an important strategy in absorbing shocks from domestic and external factors. Especially, external economic factors consist of potentially valuable information, such as the exchange rate and terms of trade (TOT), that cannot simply be ignored (Taylor, 1999; Bernanke et al., 1999). Second, the known of the interest rate interaction with the domestic and external factors may help to fine-tune the interest rate at its best form to attain the best economic outcomes.

\section{Research Objectives}

The aim of this study is to examine the monetary policy reaction function in both positive and normative approaches that encompasses the domestic and external factors, namely the inflation, the output gap, the exchange rate and the TOT; the positive approach is to determine 'by how and what' about the monetary policy reaction function, whereas the normative approach is to determine 'what ought to' be about the best monetary policy reaction function concerning the goals of the central bank (i.e., sustainable output growth and low inflation).

\section{Methodology}

In the section of methodology of the study, both the positive and normative approaches are assessed by the GMM estimates and the grid search algorithm procedure, respectively; this 


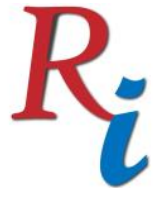

\section{Asia Proceedings of Social Sciences}

(APSS)

www.readersinsight.net/APSS

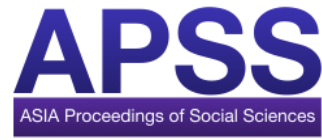

study uses the the grid search algorithm procedure proposed by Gan (2014). Particularly, the normative analysis of the optimal monetary policy reaction function is executed by calibrating the open economic model by using the GMM estimates for benchmark parameters; the results of the GMM estimates may determine the relationship among the variables of the monetary policy reaction function, i.e., the positive analysis. In this study, the GMM is a system estimates that can examine a structural economic model. To avoid a monotonous discussion of GMM estimates on a structural economic model, this study follows the method of the system GMM estimates proposed by Gan (2018). Prior to the testing of the monetary policy reaction function in both the positive and normative approaches, this study also examines the level of stationarity for dataset.

\section{Results}

The unit root results suggest that the variables in each country are not in the same order. Overall, the results of the estimated models through the positive analysis are in conformity with the expectation and they are meaningful. The estimated parameters from the positive analysis are then calibrated by using the grid search algorithm procedure to compute the best monetary policy reaction function. The finding suggests that the interest rate interacts to the domestic and external factors via positive analysis, and that the central bank should include the inflation, the output gap, the exchange rate and the TOT in its monetary policy decision making. Furthermore, the finding of the positive analysis suggests that the computed optimal monetary policy reaction function can serve as a guide to help fine-tune the interest rate at its best form to attain the best economic outcomes.

\section{Findings}

This study examines the monetary policy reaction function in both positive and normative approaches that encompasses the domestic and external factors, namely the inflation, the output gap, the exchange rate and the TOT. The findings deliver some policy implications; monetary policy via interest rate remains an important strategy in absorbing shocks from domestic and external factors, and the central bank should include important factors, namely the inflation, the output gap, the exchange rate and the terms of trade, in its monetary policy decision making that eventually help to attain the best economic outcomes.

\section{Acknowledgement}

The authors would like to thank the anonymous reviewers for their comments and suggestions. The authors acknowledge funding support from the "Fundamental Research Grants Scheme (FRGS), Ministry of Education Malaysia" under Grant 2019-0148-106-02 (FRGS/1/2019/STG07/UPSI/01/1). 


\section{References}

Bernanke, B. S., Laubach, T., Mishkin, F. S., \& Posen, A. S. (1999). Inflation targeting: Lessons from the International experience. Princeton: Princeton University Press.

Gan, P. T. (2014). The optimal economic uncertainty index: A grid search application. Computational Economics, 43(2), 159-182.

Gan, P. T. (2018). Interest rate autonomy in the presence of exchange rate stability: Evidence from 13 selected Asia Pacific countries. Journal of the Asia Pacific Economy, 23(3), 393-410.

Taylor, J. B. (1999). The robustness and efficiency of monetary policy rules as guidelines for interest rate setting by the European Central Bank. Journal of Monetary Economics, 43, 655-679.

Authors' Biography

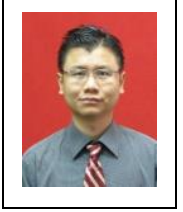

Pei-Tha Gan, Ph.D. (Financial Economics) is an Associate Professor in Faculty of Management and Economics, Universiti Pendidikan Sultan Idris, Malaysia. He was awarded his Ph.D from University of Malaya, Malaysia in 2011. His Ph.D external examiner was Professor Dr. Takatoshi Ito from Columbia University, US. He is actively involved in research where he has published articles in journals indexed by Scopus and ISI including, Computational Economics, Asian Academy of Management Journal of Accounting and Finance and International Research Journal of Finance and Economics. He is the Editor-in-chief for Journal of Contemporary Issues and Thoughts published by Sultan Idris Education University.

Kok-Jing Yee is a master student at the Universiti Pendidikan Sultan Idris, in the Faculty of Management and Economics.

Norimah Rambeli@Ramli is an Associate Professor at the Universiti Pendidikan Sultan Idris, in the Faculty of Management and Economics.

Norasibah Abdul Jalil is an Associate Professor at the Universiti Pendidikan Sultan Idris, in the Faculty of Management and Economics. 